\title{
COMMUNICATIVITY OF AUTISTIC STUDENT UTTERANCE IN LEARNING INTERACTIONS
}

\author{
Suparno, Novi Eka Susilowati, Ary Fawzi, Trisna Andarwulan, Astri Widyaruli Anggraeni* \\ (Universitas Negeri Malang)
}

\begin{tabular}{ll}
\hline A R T I C L E I N F O & A B S T R A C T \\
\cline { 2 - 3 } $\begin{array}{l}\text { Keyword: } \\
\text { communicativity, }\end{array}$ & The purpose of this study is to describe speech communication by autistic students at \\
utterance, & the SDLB Autism Laboratory of Universitas Negeri Malang. This study was \\
autistic students, & conducted on seven autistic students who had different types of autism. The data of \\
learning interactions & this study are the elicitation of verbal data in the form of grammatical lingual units and \\
& lingual units of the interaction of oral speech of autistic students in the form of words \\
& and sentences accompanied by speech context. The results of the study show four \\
& things. First, the shift of speech between teachers and students does not occur well \\
& because students are slow in responding to the stimulus from the teacher. Secondly, \\
& almost never occurs speech initiation from students. Third, there is inaccuracy and \\
incompatibility of speech responses to stimulus speech. Fourth, the communication of \\
each autistic student is different.
\end{tabular}

\section{INTRODUCTION}

Autism is a group of developmental disorders that are generally seen in the first three years of a child's life. Veskarisyanti (2018:17) explains that the term autism in Greek means itself addressed to someone when showing symptoms of living in his own world or having his own world. Meanwhile, Literature (2011: 133) reveals that autism is a disorder of brain development in children which results in a child being unable to communicate and express feelings and desires so that the relationship behavior with others becomes disrupted.

Autism symptoms are characterized by the lack or absence of spoken language, lack of initiative to engage in conversations, and reversal of use of words, especially pronouns (Monks, 2001:378). Other symptoms that emerge include life in the world itself regardless of the outside world.

Autistic children have communication problems with verbal language skills that are not good. Some of them actually experience language inability or have limited communication with the other person or speak without meaning (Bates et al., 2002). Problems related to communication in autistic children affect the emotional autistic child. Ideally the ability to communicate must be followed by language skills because the communication process influences the process of acceptance versus speaking through the language. If an autistic child is left not to communicate properly, the lack of understanding of an autistic child towards verbal or sensory stimuli or stimuli from his environment will not be responded to intact.

In verbal communication, autistic children have difficulty producing speech in terms of prosody, semantics, syntactic, and pragmatics (Bogdashina, 2005: 170). This disorder results in the inability of autistic children to read linguistic signal codes while not being able to produce different pragmatic functions. In the syntactic aspect, Tager-Flusberg et al. (2005) concluded that autistic children who did not experience delays in the acquisition of vocabulary would not experience difficulties in the syntactic

\footnotetext{
${ }^{*}$ Corresponding author.

E-mail addresses: suparno.fs@um.ac.id (Suparno)
}

ISSN : 2597-7385 (Online) - ISLLAC : Journal of Intensive Studies on Language, Literature, Art, and Culture is licensed under Creative Commons Attribution-ShareAlike 4.0 International License (http://creativecommons.org/licenses/BY/4.0/). 
aspects. However, if the child experiences delays, they will tend to use a simple syntactic form. In addition, they tend to use echolalia or repetition. In the semantic aspect, Tager-Flusberg et al. (2005) explained that autistic children with low-function experience difficulties in conceptualization, but it is different with highfunction autistic children. Autistic children with high-function have the skills to compile conceptual knowledge on the category of concrete objects, but they have different cognition strategies, starting from concrete things first then conceptualization. In the last aspect, autistic children have difficulty in pragmatic skills, such as greetings, topic initiation, topic sharing, topic development, use of deixis, anaphora, and closing of the conversation (Damico, Muller, \& Ball, 2010: 157).

Several studies or studies relating to the pragmatic aspects of autistic children have been carried out. Fatmasari Research (2011) with the title Kompetensi Berbahasa pada Anak. Autis (Autism Children Language Competence). His results show that autistic children master consonant and vowel phonemes such as /p/, /b/, /t/, /d/, /k/, /g/, /f/, /s/, /z/, /š/, /h/, /c/, /j/, /m/, /n/, /ř/, /g/, /l/, /r/, /w/, /y/, /a/, /i/, /u/, /e/, /ə/, /o/; diphthong /ai/, /au/, /oi/; and clusters /tr/ and /pr/. The phonological event that occurs is apocopy, namely the loss of sound $[\mathrm{h}]$ in the final position. Speech forms that can be found in conversations include sentences, clauses, phrases, and words. Regarding language disorders, recontextualization events occur in conversations. This event occurs in the form of topic transition in the context of land travel. The transfer topic in the form of a bus or train which then develops into a related topic, including the name of the bus or train, schedule, department, traffic, and bus or train station stops. Topic transition models can be a transition from one transfer topic to another transfer topic or back to the initial topic.

Robiah's research (2015) focused her research on pragmatic studies entitled Respon Tutur Siswa Autis terbadap Tutur Direktif Guru dalam Interaksi Pembelajaran di Kelas (Autism Student Speech Response to Teacher Directive Tutors in Classroom Learning Interactions). The results of his research show that in the learning interaction discourse in the classroom, the manifestation of the student's speech response to the teacher's directive speech is realized in various teacher directive speech motives by carrying out different response functions and expressed through a strategy of speaking directly. The higher the communication skills carried out by students, the more diverse the speech responses produced, and vice versa.

Yani's Research (2017) with the title Kemampuan Anak Penderita Autis dalam Memahami Tindak Tutur Direktif: Tinjauan Pragmatik Klinis (Ability of Children with Autism in Understanding Directive Speech: A Review of Clinical Pragmatics). The results of her research show two things. First, the ability of autistic children to receive directive speech acts is almost entirely nonverbal, especially for children with moderate (autis sedang/AAS) and severe autism (autis berat/AAB). The form of verbal responses can only be done by autistic children with mild autism (autis ringan/AAR). Secondly, the ability of autistic children in responding to directive speech acts, namely AAR has good ability and is able to respond to the two categories; AAS has a fairly good ability and is able to respond to several categories of existing categories, but not more than AAR; AAB's ability to respond to TTD is relatively low and limited. From the existing categories, $\mathrm{AAB}$ is only able to produce TTD in a single category.

This research has similarities and differences from previous research. The equation of this study with previous studies is to both see the verbal communication skills of autistic children and both study by using a pragmatic approach. The difference between this research and other research is that this study examines the speech of autistic students by adopting the theory of communicative competence. Another difference lies in the data source. The source of this research data is special school students specialized in autism (taking a class of 1 ) who have autistic variances and varying grade levels.

\section{METHODS}

This study uses a qualitative research approach. This research is also included in the type of pragmatic research. Pragmatic theory, specifically the theory of communicative competence, and the cooperative principle of Grice that is used to describe and analyze speech communication by autistic students.

The data of this study are the elicitation of verbal data in the form of grammatical lingual units and lingual units of media interaction of oral speech by autistic students in the form of words and sentences accompanied by the context of the speech. The verbal data is contained in the oral speech of autistic students when the learning process consists of speeches by autistic students when speaking in the learning process. In more detail, the form of verbal data in this study is in the form of a group of sentences in 
speech turn interaction and its context. The data is equipped with context data as nonverbal data in the form of a description of the context that supports each conversation used to interpret each speech.

Based on the exposure of the data, the data source of this study was autistic students who attended the SDLB Autism Laboratory Universitas Negeri Malang class I, II III, and V SD. In addition to observing students, researchers also observe events in learning activities, namely the atmosphere or situation and learning activities that are also used as data sources.

\section{RESEARCH FINDING AND DISCUSSION Research Findings}

The study of speech communication by autistic students shows four things. First, the shift of speech between teachers and students does not occur well because students are slow in responding to the stimulus from the teacher. Secondly, almost never occurs speech initiation from students. Third, there is inaccuracy and incompatibility of speech responses to stimulus speech. Fourth, the communication of each autistic student is different. Each of these findings is explained as follows.

First, the shift of speech between teachers and students does not occur well because students are slow in responding to the stimulus from the teacher. In fact, sometimes students are not only slow to respond to the teacher's speech, but also cannot respond to the teacher's speech. This can be seen in the following conversation quote.

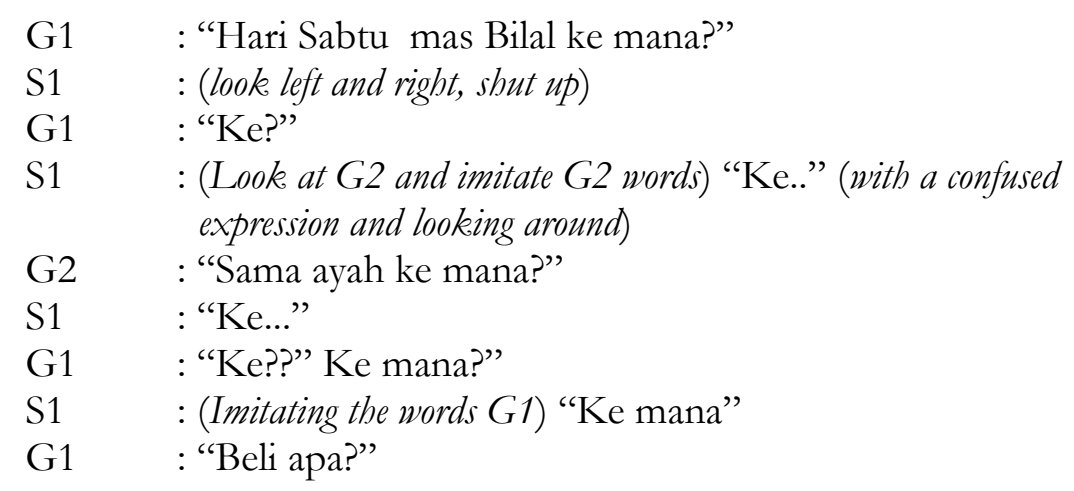

The quotation above shows the students' inability to respond to the teacher's speech. The conversation quote shows that students are only able to repeat the teacher's speech, rather than responding to the teacher's question.

Second, in conversations between teachers and autistic students, there is almost no initiation speech from students. That is, at every conversation, initiation and stimulus always come from the teacher. This can be seen in the following excerpt of the quote.

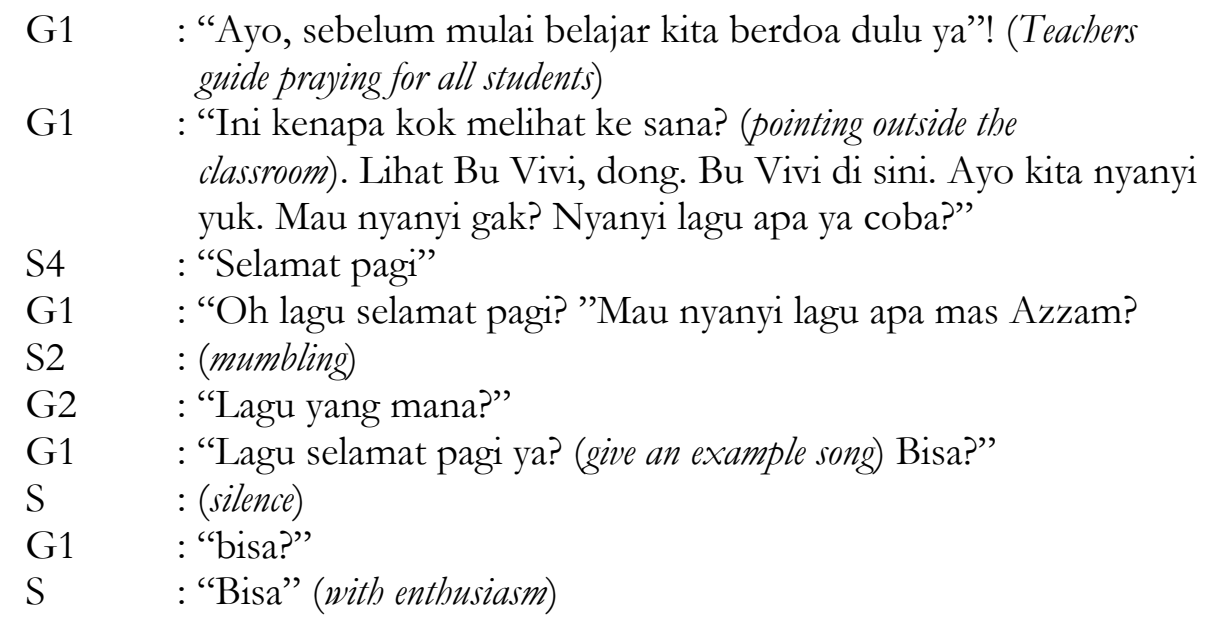

In the quotation above, it appears that the initiation of the conversation was carried out by the teacher. In fact, when the topic of speech changes, initiation and stimulus are still carried out by the teacher. Students tend to only give response speeches and sometimes do not give any response. 
Third, there is inaccuracy and incompatibility of speech responses to stimulus speech. The inaccuracy and incompatibility of speech respond to the speech of the stimulus appears in the following excerpt of the quote.

G1 : "Mbak Imel hari Sabtu ke mana?"

S5 : Bangun tidur (turn to G1)

G1 : "Oh, bangun tidur?"

G1 : "Jadi ayah sama ibu ke mana?"

S5 : "Ayah sama ibu ... (mumble, can't answer, look, away from G1)

G1 : "Ayah sama ibu jalan-jalan? (approached S5 while holding his

shoulder) Ayah sama ibu jalan-jalan ke...?"

S5 : (Stare at G2) jalan-jalan ke...?"

G1 : "Bantuin pak riza” (ask for G2 help)

G2 : "Jalan-jalan naik apa?"

S5 : (muttering)

From the fragment above, it appears that students often repeat the last few words of the sentence expressed by the teacher. In fact, students do more nonverbal movements when learning in class. The sentence uttered by students is also not very clear or muttering, as if it does not respond to the teacher's speech. Students are not able to respond well because the response delivered is not in accordance with the stimulus given. In fact, the teacher needs to repeatedly ask questions and even provide answers to his own questions so students can communicate verbally.

Fourth, the grammatical competence of students with autism between students and students is different. This can be seen in the following speech.

G1 : Ditulis sendiri angkanya nak! Sudah? Nomor satu. Ayo, sudah? Nomor satu. Nomor satu. Sebutkan bagian-bagian dari tumbuhan? Coba kamu sebutkan dulu, bagian dari tumbuhan itu ada apa saja?"

S3 : "Akar, batang, bunga..."

G1 : "Iya, ayo. Terus? Oke. Yang nomor dua, benda yang ada di langit waktu malam hari itu apa saja?"

S3 : "Bintang? Bulan?"

G1 : "Ayo, nomor lima, bagian tubuh yang digunakan untuk mendengar adalah...?"

S3 : "Telinga."

G1 : "Ya, ditulis! Nomor enam. Meja, kursi, papan tulis adalah bendabenda yang ada di?"

S3 : "Ruang kelas

The fragment of the speech quotations between the teacher and the students above shows that students have fairly good grammatical competence. This is because students have the knowledge to produce a language that is reasonable, not strange, and accepted in a rule. Mastery of consonant and vowel phonemes is also clear. Judging from the competence of the discourse, students understand the discourse built by the teacher in classroom learning. Students can also answer a number of questions asked by the teacher so that the goals to be achieved by the teacher can be achieved.

The results of the study also showed that there were also students with low grammatical competence. The low grammatical competence of these students can be seen from repetitive speech, namely repeating the speech delivered by the teacher. This can be seen in the following snippet of speech.

G1 : "Hari sabtu mas Bilal ke mana?"

S1 : (look left and right, shut up)

G1 : "Ke?"

S1 : (Look at G2 and imitate G2 words) "Ke.." (with a confused 


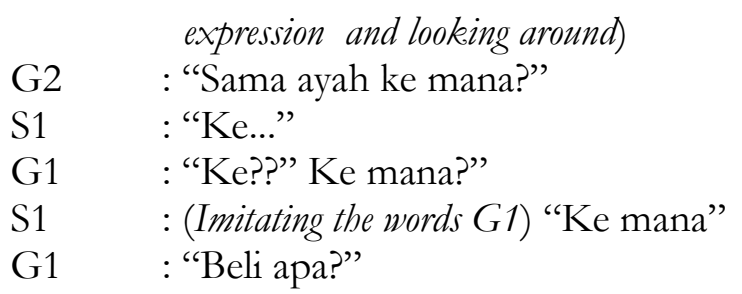

In the speech above, the teacher tries to fish by giving questions to students so he wants to tell about his experiences on vacation. The teacher continues to give questions. However, students keep repeating the final words spoken by the teacher.

\section{Discussion}

To speak communicatively, an ability needed by Chomsky (1967) is called competence. Competence is a basic knowledge of the language system (LAD), grammar rules, vocabulary, all language knick-knacks, and how to use them in a unified manner. Competence is in the human mind so that it is abstract and cannot be observed. Furthermore, Chomsky explained that what is meant by this competency is linguistic competence or grammatical competence.

In reality, just grammatical competence is not enough to produce communicative language. Therefore, Hymes then criticized the concept of competency put forward by Chomsky and then gave rise to a new term called communicative competence. Communicative competence is a person's ability to convey and interpret interpersonal messages in certain contexts. Based on this explanation, it can be concluded that communicative competence can be used to measure speech communication.

The results of the study showed that students' ability to attend shifts was slow, sometimes even unable to follow the speech shift that occurred in the classroom. In connection with slowness or the inability of students to attend good speech shifts, this can be understood from the inability of people with autism to be able to relate to other people. This is in line with the opinion of Reed (1991) which states that autistic children have problems in building relationships with others because of their inability to communicate and to understand someone's feelings. In addition, people with autism also experience very complex problems. These problems, including motor, sensory, cognitive, intrapersonal, interpersonal, selfcare, production, and leisure (busy with him/herself).

The inability of autistic students to build communication with other people also causes no initiations that arise from students during the learning process takes place. During the learning process takes place, the conversation that occurs is always initiated by the teacher and never initiated by students. The inability of students to initiate conversations can be understood because students experience difficulties in establishing communication with others. This is reinforced by the opinion of Parwoto (2007: 3) which states that autistic disorder is a condition of deviation in children in communicating and interacting socially. One effect of this deviation is the inability of children to initiate conversations. Moreover, autism is a preoccupation with one's own mind and imagination or in other words more oriented to his own subjective mind than to see the reality or reality of everyday life so that people with autism are called people who live in their "nature" (Gulo, 1982).

The results of the study showed that there was an inaccurate communication between the teacher and students. The inaccuracy can be seen from the inability of students to respond to the conversation stimulus from the teacher. This causes the teacher to provide repetitive stimulus to students so students understand the stimulus and then can respond to the stimulus. However, in reality not all students respond to the stimulus given by the teacher. In fact, it is not uncommon for the stimulus given by the teacher to be rewarded with a response in the form of repetition of stimulus from the teacher so that it takes a long process and is not easy to make an autistic child understand the stimulus delivered. This is in line with the opinion of Sunardi \& Sunaryo (2007: 197) which states that one of the peculiarities of autistic children is having limited ability to capture cues originating from the environment so that they also have difficulty in responding.

In conversation, speakers and speakers need to pay attention to the smooth conversation. Therefore, speakers and speakers need to pay attention to the Cooperative Principle because the principle of cooperation regulates the speech of a speaker so that the conversation that is woven is smooth and coherent. 
The application of the Cooperative Principle needs to be carried out in various forms of conversation, including conversations in classroom learning interactions. However, the Cooperative Principle consisting of four maxims cannot be applied to conversations in learning interactions in the class of autistic students. This is based on the consideration that conversations between teachers and autistic students are conversations that are "abnormal" so that the parameters of the Cooperative Principle for the sake of the realization of smooth communication cannot be used. For example, in conversations between teachers and students in the autistic class, teachers often repeat stimulus speeches to students. From the perspective of the Cooperative Principle, repetition of the stimulus speech violates the maxim of the way because the teacher as the speaker gives the same information repeatedly. According to Grice (1975), to make conversation effective, speakers do at least four principles, namely (1) avoid the same statement, (2) avoid being intimidated, (3) avoid long and long-winded statements, and (4) try to speak regularly. However, this principle cannot be done in conversations with autistic children.

In the context of the interaction of teachers and autistic students, repetition needs to be done because autistic students cannot understand the speech of the stimulus if the speech of the stimulus is only delivered one time so that the speech of the stimulus must be repeated so that students become understanding. From this case, it appears that the quantity maxim that requires the delivery of ideas in a concise, clear, and complete manner cannot be applied in speech with autistic students. This finding also rejects the opinion of Wijana (1996) which states that the Cooperative Principle, especially quantity maxim, needs to be applied so that the speech is always relevant to the context, clear, and easy to understand, solid and concise, and always on issues so that the interlocutors don't spend time.

In the interaction of learning in the classroom, autistic students are not able to respond to the teacher's stimulus speech properly. The teacher needs to repeatedly ask questions and even provide answers to his own questions so students can communicate verbally. The conditions experienced by these students are in line with the opinion of Widihastuti (2007:17) which states that the characteristics of autistic children in terms of communication, both verbal communication and nonverbal communication, are characterized by slow or no language development at all; looks like deafness, difficulty speaking or ever talking then vanishing; sometimes the word used does not match the meaning; babbling meaninglessly over and over, the language is not understood by others; and happy to imitate or echolalia (check also Kanner, 1943; Azwandi, 2005).

The results also showed that students could not provide an appropriate response to the teacher's stimulus speech, for example the teacher asked students to share experiences experienced by students the day before, students did not retell their experiences, but instead repeated the teacher's speech. The inability of students to provide the right response certainly inhibits the smooth communication. However, this incompetence cannot be said to be a violation of the Cooperation Principle because basically an autistic child is indeed having difficulty capturing the information conveyed by the addressee so that he is unable to give the correct response speech by the teacher's stimulus speech. This is in line with the opinion of Gulo (1982) which states that autism is a preoccupation with one's own mind and imagination or in other words more oriented to his own subjective thoughts so that people with autism have difficulty understanding other people or objects.

The results of the study also showed that the speech communicative of autistic students studied was different. This difference can be explained in terms of differences in the types of autistic students. This study was conducted on seven autistic students, each of whom had a different type of autism. Of the seven students, there were students who were included in the category by Tager-Flusberg et al. (2005) called autism with high-function and low-function autism. High-function autistic children still have the ability to communicate with their speech partners. That is why, there are some autistic children with this category who can still attend public school learning in inclusive classes. Meanwhile, low-function autistic children do not have the ability to communicate with speech partners. The ability of autistic children with conditions is caused by the condition that high-function autistic children have the skills to construct conceptual knowledge on the category of concrete objects and they have the ability to communicate them to others. As for low-function autistic children, they experience difficulties in practical skills so they cannot communicate the topic of conversation (Damico, Muller, \& Ball, 2010: 157). 


\section{CONCLUSION}

The results of this study indicate that speech responses to stimulus speech are slow. This results in the stimulus need to be repeated so that students can understand the stimulus so they can respond to the stimulus given by the teacher. However, it turns out that the speech responses given by students tend not to be spontaneous and even just repeat the speech of the stimulus given by the teacher. In fact, the results of the study also showed that there were never any initiation speeches from students. This condition causes the speech turn to be not smooth. The results of the study also show that students' communicative competencies vary depending on the type of autism.

\section{REFFERENCES}

Azwandi, Y. 2005. Mengenal dan Membantu Penyandang Autisme. Jakarta: Departemen Pendidikan Nasional.

Bates, E., Thal, D., Finlay, B., \& Clancy, B. 2002. Early language development and its neural correlates. Dalam Segalowitz, S. J., \& Rapin, I (Ed). Handbook of neuropsychology 2nd edition (Hal. 1-39). Diperoleh dari people.psych.cornell. edu/.../EB,DT,BEC,BLFRapi.

Bogdashina, O. 2005. Communication Issues in Autism and Asperger Syndrome: Do we speak the same language? London: Jessica Kingsley Publishers.

Canale, M. \& Merril S. 1980. Approaches to Communicative Competence. Singapore: SEAMEO Regional Language Center.

Damico, J. S., Müller, N., \& Ball, M. J. 2010. The Handbook of Language and Speech Disorders. United Kingdom: Blackwell Publishing Ltd. Diperoleh dari http:/ /en.bookfi.org.

Fatmasari, F. 2011. Kompetensi Berbahasa pada Anak. Autis. Tesis tidak diterbitkan. Yogyakarta: Fakultas Ilmu Budaya UGM.

Grice, H. P. 1975. Logic and Conversation. New York: Oxford University Press.

Gulo, Dali.1982. Kamus Psikologi. Bandung: Penerbit Tonis.

Kanner, L. 1943. Autistic Disturbance of Affective Contact. Johns Hopkins University.

Monks, F.J. 2001. Psikologi Perkembangan Pengantar Dalam Berbagai Bagian. Yogyakarta: Gadjahmada University Press.

Parwoto. 2007. Strategi Pengajaran Anak Berkebutuhan Khusus. Jakarta: Departemen Pendidikan Nasional.

Reed, L.K. 1991. Quick Reference to Occupational Therapy. Maryland: Aspen Publishing Inc.

Robiah, S. 2015. Respon Tutur Siswa Autis terbadap Tutur Direktif Guru dalam Interaksi Pembelajaran di Kelas. Tesis tidak diterbitkan. Malang: PPS Universitas Negeri Malang.

Sastra, G. 2011. Neurolinguistik suatu Pengantar. Bandung: CV Alfabeta.

Savignon, S.J. 1972. Communicative Competence. Theory and Practice. Reading, Mass. Addison and Wiley.

Sunardi \& Sunaryo. 2007. Intervensi Dini Anak Berkebutuhan Kbusus. Jakarta: Departemen Pendidikan Nasional.

Tager-Flushberg, dkk. 2005. 'Language and communication in autism'. Dalam Volkmar, F. \& Klin, A. (2005). 'Issues in the classification of autism and related condition. [ed.3] Handbook of Autism and Pervasive Development Disorders. Hlm. 6-41, New Jersey: John Wiley \& Sons, Inc.

Veskarisyanti, G.A. 2008. Terapi Autis Paling Efektif dan Hemat. Yogyakarta: Pustaka Anggrek.

Widihastuti, S. 2007. Pola Pendidikan Anak. Autis. Yogyakarta: CV Datamedia.

Wijana, I Dewa Putu. 1996. Dasar-dasar Pragmatik. Yogyakarta: Andi.

Yani, N. F. 2017. Kemampuan Anak Penderita Autis dalam Memahami Tindak Tutur Direktif: Tinjauan Pragmatik Klinis. Jurnal Retorika, Volume 10: 1, hlm. 1—71, Februari 2017. 